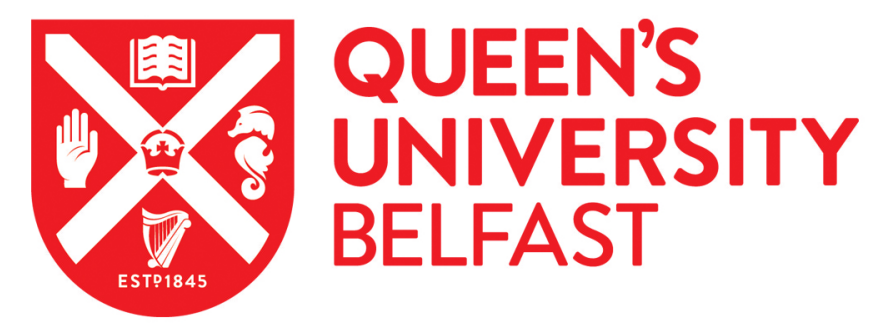

\title{
Phylogenetic analyses of bacteria associated with the processing of iru and ogiri condiments
}

Ademola, O. M., Adeyemi , T. E., Ezeokoli , O. T., Ayeni , K. I., Obadina , A. O., Somorin, Y. M., Omemu, A. M., Adeleke, R. A., Nwangburuka, C. C., Oluwafemi , F., Oyewole , O. B., \& Ezekiel, C. N. (2018). Phylogenetic analyses of bacteria associated with the processing of iru and ogiri condiments. Letters in Applied Microbiology, 67(4), 354-362. https://doi.org/10.1111/lam.13040

Published in:

Letters in Applied Microbiology

Document Version:

Peer reviewed version

Queen's University Belfast - Research Portal:

Link to publication record in Queen's University Belfast Research Portal

Publisher rights

(C) 2018 The Society for Applied Microbiology. This work is made available online in accordance with the publisher's policies. Please refer to any applicable terms of use of the publisher.

\section{General rights}

Copyright for the publications made accessible via the Queen's University Belfast Research Portal is retained by the author(s) and / or other copyright owners and it is a condition of accessing these publications that users recognise and abide by the legal requirements associated with these rights.

Take down policy

The Research Portal is Queen's institutional repository that provides access to Queen's research output. Every effort has been made to ensure that content in the Research Portal does not infringe any person's rights, or applicable UK laws. If you discover content in the Research Portal that you believe breaches copyright or violates any law, please contact openaccess@qub.ac.uk. 
MR. OBINNA T EZEOKOLI (Orcid ID : 0000-0003-1819-8804)

DR. YINKA MORAKINYO SOMORIN (Orcid ID : 0000-0001-8437-6694)

DR. CHIBUNDU EZEKIEL (Orcid ID : 0000-0002-2113-2948)

Article type : Original Article

\section{Phylogenetic analyses of bacteria associated with the processing of iru and ogiri} condiments

Oluwatoyin M. Ademola ${ }^{a, \#}$, Taiwo E. Adeyemi ${ }^{\mathrm{b}, \#}$, Obinna T. Ezeokoli ${ }^{\mathrm{c}, \mathrm{d}}$, Kolawole I. Ayeni ${ }^{\mathrm{e}}$, Adewale O. Obadina ${ }^{\mathrm{a}}$, Yinka M. Somorin ${ }^{\mathrm{f}, \$}$, Adebukola M. Omemu ${ }^{\mathrm{g}}$, Rasheed A. Adeleke ${ }^{\mathrm{c}, \mathrm{d}}$, Cyril C. Nwangburuka ${ }^{h}$, Flora Oluwafemi ${ }^{b}$, Olusola B. Oyewole ${ }^{a} \&$ Chibundu N. Ezekiel ${ }^{e^{,}}$

${ }^{a}$ Department of Food Science and Technology, Federal University of Agriculture, Abeokuta, P.M.B. 2240, Ogun State, Nigeria. ${ }^{b}$ Department of Microbiology, Federal University of Agriculture, Abeokuta, P.M.B. 2240, Ogun State, Nigeria. 'Microbiology and Environmental Biotechnology Research Group, Agricultural Research Council-Institute for Soil, Climate \& Water 600, Belvedere Street, Arcadia, 0001, Pretoria, South Africa. ${ }^{d}$ Unit for Environmental Science and Management, North-West University (Potchefstroom Campus), Private Bag x6001, Potchefstroom 2531, South Africa.

${ }^{e}$ Department of Microbiology, School of Science and Technology, Babcock University, Ilishan Remo, Ogun State, Nigeria. ${ }^{f}$ Microbiology, School of Natural Sciences, National University of Ireland, Galway, Ireland. ${ }^{g}$ Department of Hospitality and Tourism Management, Federal University of Agriculture, Abeokuta, P.M.B. 2240, Ogun State, Nigeria. ${ }^{h}$ Department of Agriculture, School of Science and Technology, Babcock University, Ilishan Remo, Ogun State, Nigeria.

\#Authors contributed equally.

${ }^{\$}$ Present Address: School of Pharmacy, Queen's University Belfast, Belfast, UK

This article has been accepted for publication and undergone full peer review but has not been through the copyediting, typesetting, pagination and proofreading process, which may lead to differences between this version and the Version of Record. Please cite this article as doi: 10.1111/lam.13040

This article is protected by copyright. All rights reserved. 
${ }^{*}$ Corresponding author: Dr. Chibundu N. Ezekiel, Department of Microbiology, Babcock University, Ilishan Remo, Ogun State, Nigeria

Email: chaugez@gmail.com; Telephone: +234-7038167130

Running title: Bacterial succession in iru and ogiri processing

\section{Significance and Impact of Study}

Iru and ogiri are important condiments used for flavour enhancement in foods and serve as protein substitutes in diets among rural populations across West Africa. Consumption of these condiments is growing reinforcing the need to scale up their production. Production of these condiments includes spontaneous fermentation, which often leads to inconsistent product quality and unguaranteed safety. This study has demonstrated the bacterial succession in iru and ogiri processing and highlights species that could be selected and exploited for starter culture development. This study provides a starting point to produce quality and microbiologically safe iru and ogiri condiments.

\section{Abstract}

Analysis of the bacterial community dynamics during the production of traditional fermented condiments is important for food safety assessment, quality control and development of starter culture technology. In this study, bacteria isolated during the processing of iru and ogiri, two commonly consumed condiments in Nigeria, were characterised based on phylogenetic analyses of the bacterial 16S rRNA gene. A total of 227 isolates were obtained and clustered into 12 operational taxonomic units (OTUs) based on $97 \%$ 16S rRNA gene similarity. The OTUs spanned three phyla (Firmicutes, Actinobacteria and Proteobacteria), and nine genera: Acinetobacter, Aerococcus, Bacillus, Enterococcus, Enterobacter, Lysinibacillus, Micrococcus, Proteus and Staphylococcus.

This article is protected by copyright. All rights reserved. 
OTUs closely related to species of Bacillus dominated the processing stages of both condiments. Although no single OTU occurred throughout iru processing stages, an OTU (mostly related to $B$. safensis) dominated the ogiri processing stages indicating potentials for the development of starter culture. However, other isolates such as those of Enterococcus spp. and Lysinibacillus spp. may be potential starters for iru fermentation. Presumptive foodborne pathogens were also detected at some stages of the condiments' processing, possibly due to poor hygienic practices.

Keywords: 16S rRNA gene; condiment; fermented foods; iru; ogiri; succession.

\section{Introduction}

Leguminous oilseeds such as those of African locust bean (Parkia biglobosa) and melon (Colocynthis citrullus) are widely fermented to produce condiments in many West African countries (Oguntoyinbo 2012). These condiments constitute a significant proportion of the protein content of diets in rural populations across West Africa (Achi 2005; Adedeji et al. 2017). In Nigeria, seeds of African locust bean and melon are fermented into iru and ogiri condiments respectively, though castor oil bean (Ricinus communis) is also used for ogiri production in some parts (Odunfa 1981, 1982, 1985).

Iru and ogiri are consumed mainly by rural dwellers where they serve as low-cost additives that enhance soup flavour (Odunfa and Oyewole 1986; Oyeyiola 1988). The processing steps for iru and ogiri production are very similar and generally involve sorting of the dried seeds, washing, boiling, dehulling, and fermentation at ambient temperature for about 72 hours and 120 hours for iru and ogiri, respectively (Odunfa 1982; Oyeyiola 1988). Processing of iru and ogiri from the raw materials is usually carried out on a small scale by rural dwellers in an uncontrolled environment and by spontaneous fermentation, which often

This article is protected by copyright. All rights reserved. 
lead to inconsistent condiment quality as well as unguaranteed safety (with possible presence of pathogens) from one batch of production to another.

There are several reports available on the bacterial diversity in retailed iru (Odunfa and Oyewole 1986; Osho et al. 2009; Aderibigbe et al. 2011; Adewumi et al. 2013; Adedeji et al. 2017) and retailed ogiri (Odunfa 1982; Aniche et al. 1993; Akinyele and Oloruntoba 2013; Adedeji et al. 2017). However, besides the studies by Aderibigbe et al. (2011), Adewumi et al. (2013), and Adedeji et al. (2017), where molecular methods were applied in exploring the bacterial diversity in the retailed condiments, other diversity studies depended solely on classical microbiological methods of identification, which when compared to phylogenetic markers are known to be more prone to low taxonomic resolutions and are often misleading (Janda and Abbott 2007). Some of the previous studies presented a plethora of bacterial species including presumed fermenters and notable pathogens. Besides, only a few studies have attempted to explore the bacterial dynamics in iru (Odunfa 1981; Adelekan and Nwadiuto 2012) and ogiri (Barber et al. 1988; David and Aderibigbe 2010; Odibo et al. 2012), providing information that could be potentially useful for starter culture selection and controlled fermentation.

The application of molecular methods in exploring the diversity and dynamics of bacteria at major stages of processing of the two condiments are, however, very limited. A combined understanding of the bacterial diversity of the retailed products and bacterial succession during the fermentation of these condiments will provide information necessary for distinguishing actual fermenters from undesirable species and chance contaminants that might have been introduced during pre-processing, processing and post-processing stages of production. Since little is known about the bacterial diversity and successional patterns during iru and ogiri processing, this study employs 16S rRNA gene-based phylogenetic analysis to characterise bacteria associated with the processing of iru and ogiri. This will provide robust data on the bacterial successional patterns of both condiments for better food quality management.

This article is protected by copyright. All rights reserved. 


\section{Results and Discussion}

A total of 227 bacterial isolates were recovered during the processing stages of iru (114 isolates) and ogiri (113 isolates). The 16S rRNA-based taxonomic diversity of these isolates is presented in Table 1.

Taxonomically, of the isolates obtained from the processing stages of iru, the majority belonged to the phylum Firmicutes $(91.23 \%)$, while the remaining belonged to Proteobacteria (6.14\%) and Actinobacteria (2.63\%) (Fig. 1). The isolates were close relatives of species belonging to the genera Aerococcus, Bacillus, Enterococcus, Lysinibacillus, Micrococcus and Proteus (Fig. 1). Isolates obtained from the ogiri processing stages belonged to the phyla Firmicutes (67.49\%), Actinobacteria $(23.01 \%)$ and Proteobacteria (11.5\%) (Fig. 2). At the genus taxa level, the isolates were close relatives of Acinetobacter, Bacillus, Enterobacter, Enterococcus and Staphylococcus. Species of Bacillus and Enterococcus were mostly associated with the African locust bean and its processing stages into iru, whilst only Bacillus species were common in ogiri processing stages. Additionally, Lysinibacillus was found during iru processing. The prevalence of Bacillus species in these condiments, as well as in other similar fermented bean condiments have been previously reported (Adewunmi et al. 2013; Ezeokoli et al. 2016a; Adedeji et al. 2017). Also, closely related species of Acinetobacter, Enterococcus, and Staphylococcus have been associated with these condiments and/or other similar fermented seed condiments (Nwosu and Ojimelukwe 1993; Achi 2005; Ezeokoli et al. 2016a).

All 16S rRNA gene sequences obtained from both iru and ogiri processing stages clustered into 12 operational taxonomic units (OTUs), with eight OTUs obtained from the processing of iru and seven OTUs detected during ogiri processing stages (Table 1). Phylogenetic reconstruction revealed that the 16S rRNA gene sequences/OTUs belonged to

This article is protected by copyright. All rights reserved. 
three major phylogenetic clades (Fig. 3) and that the clades were monophyletic, indicating close relatedness of sequences to one another and to sequences in the GenBank.

In this study, Bacillus species were dominant during iru and ogiri processing, with at least one species occurring at every stage of processing prior to fermentation of iru. This observation is similar to previous studies on traditionally fermented legume condiments such as soy-daddawa (Ezeokoli et al. 2016a) and thua nao (Chukeatirote et al. 2006). Species of Bacillus have also been previously reported to dominate in iru (Odunfa, 1981; Oyeyiola, 1988; Aderibigbe et al. 2011; Oguntoyinbo 2012; Adewumi et al. 2013; Adedeji et al. 2017) and ogiri condiments (Odunfa 1982; Akinyele and Oloruntoba 2013; Adedeji et al. 2017). The Bacillus species recovered in this study spanned three taxonomic groups, and the partial 16S rRNA gene sequencing was unable to completely resolve their exact taxonomies, hence whole genome sequencing of the Bacillus isolates is recommended for the final selection of starter cultures for both condiments.

The OTU groupings of bacterial species observed during the processing stages of iru and ogiri are presented in Fig. 4. Species of Bacillus (belonging to OTUs 1, 2 and 6) dominated iru processing, with OTU 1 and OTU 2 being associated with all stages, except in the river sand sediment-coated seed (Fig. 4a). On the other hand, OTUs 3 and 4 comprising species of Enterococcus and Lysinibacillus, respectively, were isolated from one or more processing stages, as well as in the fermented product. The source of these bacterial OTUs along the processing chain are likely due to these species being seed-borne, associated with the processing utensils, and/or introduced by the processor (Iwuoha and Eke 1996). The presence or isolation of specific OTUs (e.g. OTU 1 and OTU 2 during iru processing and OTU 5 during ogiri processing) at only certain stages may be due to several reasons. Firstly, this could be due to constraints imposed by the prevailing conditions (treatment) at specific stages and the differential abundance and adaptation of species to the processing conditions. Secondly, the microbial population in the seeds, processing materials and

This article is protected by copyright. All rights reserved. 
utensils may predispose certain species to be more likely isolated (or missed) at certain stages. Thirdly, culture-based isolation of species are prone to the likelihood of missing out similar morphotypes (similar colony appearance) but phylogenetically distinct species and lastly, solid-state fermentations like iru and ogiri fermentations, are prone to substrate heterogeneity which may contribute to the underestimation of true species richness if representative samples are not analysed. However, attempts were made to collect a representative samples in the present study, and thus, the observed disappearance of species (e.g. OTU 2 during iru processing) at the fermentation stage are most likely not due to sample heterogeneity. It is now well documented that culture-based techniques for the study of microbial diversity are prone to underrepresentation of species (Ercolini 2003). Hence, future studies employing high-throughput culture-independent molecular analysis are required to obtain a deeper coverage of the bacterial diversity and dynamics during the processing of these condiments.

No specific OTUs was associated with all stages of iru processing (Fig. 4), suggesting inter-specific competition in several stages of the successional chain, which could lead to exclusion of some species in successive stages, creation of conducive environment for new colonizers, and induction of variable successional patterns in the species (Odunfa 1981; Odunfa and Oyewole 1986). Also, reasons stated earlier on the limitation of culture-dependent microbiological analysis may contribute to the observation of no specific OTUs at all stages of iru production. Furthermore, the variable bacterial successional patterns observed between pre-fermentation stages and fermented products could be due to variable responses of bacterial species to changes in $\mathrm{pH}$ and other biochemical parameters within the fermenting substrates (African locust bean and melon seeds) (Achi 2005). The fermentation of iru and ogiri are typical alkaline fermentations with characteristic rise in pH from near neutrality to alkalinity (Odunfa 1982; Achi 2005). Similarly, the $\mathrm{pH}$ recorded during the processing of the African locust bean seeds to iru ranged from 6.0 in the raw seeds to 6.43 after $24 \mathrm{~h}$ of fermentation. For the processing of ogiri from the

This article is protected by copyright. All rights reserved. 
melon seeds, the $\mathrm{pH}$ increased from 5.58 in the raw melon seeds, thru 5.89 after boiling, to 8.38 during fermentation. The $\mathrm{pH}$ values of the final products (ogiri) of the mashed and unmashed seeds were 7.82 and 7.64 , respectively.

OTUs 5 and 8 , which included potential pathogenic bacterial species Proteus mirabilis and Aerococcus urinaeequi, were only isolated during the stages prone to direct contact with the processor. No OTU was isolated from all stages of iru processing (Fig. 4a). During ogiri processing, Bacillus species (OTU 1) dominated the processing chain (Fig. 4b). Bacillus safensis was the dominant species associated with all the stages of ogiri production, except the fermentation stage of the unmashed (Batch B) seeds, where B. altitudinis was found to be dominant. As with iru processing, potentially pathogenic bacterial species belonging to OTUs $5,7,9,10$ and 11 were isolated mainly from the stages involving direct contact of the processor with the product (Fig. $4 \mathrm{~b}$ and Table 1).

The recovery of $B$. safensis (OTU 1) and other species of Bacillus at all processing stages of iru processing and at almost all stages of ogiri processing, could be attributed in part to their ability to adapt to extremely harsh conditions and to out-compete other microorganisms (Cazorla et al. 2007; Kothari et al. 2013). Furthermore, the alkaline fermentation of the locust bean and melon substrates, which is often characterised by an increase in $\mathrm{pH}$ due to protein hydrolysis to produce amino acids, ammonia and peptides (Ouoba et al. 2003; Achi 2005), may have also favoured their proliferation than the other recovered species. In view of the successional data obtained, it is obvious that $B$. safensis and other species of Bacillus from ogiri, as well as the Bacillus, Enterococcus and Lysinibacillus genera from iru processing could play functional roles in the fermentation of the condiments. More efforts are, however, required to investigate the successional patterns of iru and ogiri processing using metagenomics tools which best elucidates community dynamics, and to study the functional roles of species within these frequently recovered genera.

This article is protected by copyright. All rights reserved. 
The recovery of Staphylococcus species that belong to the same OTU only at the end of the processing of one batch of the fermented ogiri suggests possible contamination from leaf wrappings, fermentation materials and/or handlers (Achi 2005). Furthermore, the recovery of potential pathogens such as Enterococcus faecium and $P$. mirabilis in both fermented condiments, and the additional presence of $P$. mirabilis in some stages of processing where processors directly handle the intermediary products, raise concerns regarding the personal hygiene of processors and the hazards associated with the consumption of these condiments. It should also be noted that $P$. mirabilis was recovered in retailed iru and ogiri (Adedeji et al. 2017) suggesting that handling by processors is the major source of contamination of the condiments.

In conclusion, this study has provided data on the diverse bacteria populations associated with iru and ogiri processing. The study has further shown that species of Bacillus (B. encimensis and B. safensis), Enterococcus (E. dispar), and Lysinibacillus ( $L$. fusiformis and $L$. macroides) may be the functional bacteria in iru processing while $B$. safensis may be the choice starter species for ogiri processing. There is also evidence that poor hygiene could affect the quality of the final products, and pose a public health threat to consumers. Thus, practical steps to improve the processing of the two condiments may include educating local processors on improvement of personal hygiene during processing such as use of gloves when direct contact with processing intermediate or final product is required, proper cleaning of processing equipment, and an exploration of the possibility of controlling the processing conditions. The latter is, however, possible when starter cultures have been carefully selected and developed.

This article is protected by copyright. All rights reserved. 


\section{Materials and Methods}

\section{Production of iru and ogiri condiments}

African locust bean ( $P$. biglobosa) and melon (C. citrullus) seeds purchased from a local market in Abeokuta, Nigeria, were processed into iru and ogiri, respectively. Iru was produced from the bean seeds by following the method commonly used by local processors in Abeokuta as shown in (see Fig. S1a in Supplementary Information). Briefly, the bean seeds were first sorted to remove defected seeds prior to washing in tap water. The washed seeds were boiled for $24 \mathrm{~h}$ and dehulled using a mechanical dehuller. Thereafter, dehulled seeds were coated with river sand sediment (locally called "oloro") for $30 \mathrm{~min}$, rinsed in tap water and boiled in brine for $2 \mathrm{~h}$. After boiling, seeds were placed in a jute sack and allowed to ferment for $24 \mathrm{~h}$ at ambient temperature.

For ogiri production, melon seeds were processed as shown in Fig. S1b (in Supplementary Information). Briefly, shelled melon seeds were sorted to remove defective seeds, and then washed in tap water. The washed seeds were boiled for $6 \mathrm{~h}$, dehulled using a mechanical dehuller, and then boiled for a further $2 \mathrm{~h}$. Thereafter, the seeds were divided into two lots. Seeds in the first lot (Batch A) were mashed in a mortar prior to fermentation for $4 \mathrm{~d}$ (Asagbra et al. 2012), while seeds in the second lot (Batch B), as a modified method, were fermented prior to mashing (see Fig. S1b in Supplementary Information). The fermented products of each lot were then wrapped in banana leaves and dried by smoking (kept near a fire place) for $4 \mathrm{~h}$ prior to mashing into paste in a mortar.

\section{Sampling during iru and ogiri processing}

During iru processing, raw seeds, boiled seeds, dehulled seeds, river sand sedimentcoated seeds (oloro), reboiled seeds, and fermented product (iru) were sampled, whilst the shelled melon seeds, washed seeds, boiled seeds, and fermented product (ogiri) of both

This article is protected by copyright. All rights reserved. 
batches (mashed and unmashed) were sampled during ogiri production. The samples were collected into sterile plastic bags, stored at $4^{\circ} \mathrm{C}$ and analysed within $24 \mathrm{~h}$.

\section{Determination of $\mathrm{pH}$ of samples}

For $\mathrm{pH}$ determination, sample homogenate $(1: 20 \mathrm{w} / \mathrm{v}$ in distilled water) were analysed using a pH meter (HANNA 2210, Woonsocket, RI, USA).

\section{Microbiological analysis of samples from the production of condiments}

\section{Isolation}

Bacteria were isolated from ten-fold dilutions of samples by the pour plate method. Nutrient agar (LAB M, Heywood Lancashire England) was used for the isolation of aerobic bacteria, MacConkey agar (LAB M, Heywood Lancashire England) for coliforms, and Mannitol salt agar (Oxoid, Basingstoke, Hampshire, England) for staphylococci. The inoculated culture media were incubated aerobically at $37^{\circ} \mathrm{C}$ for $48 \mathrm{~h}$. Distinct colonies observed on the culture plates were successively streaked on fresh Nutrient agar, Mannitol salt agar or MacConkey agar plates to obtain pure cultures.

\section{$16 S$ rRNA gene-based phylogenetic analyses of isolates}

For phylogenetic analyses, genomic DNA was extracted from pure cultures of isolates by using the ZR fungal/bacterial DNA extraction kit (Zymo Research, California, USA) according to the manufacturer's instruction. Thereafter, the partial 16S rRNA gene was amplified using universal bacterial primers $27 \mathrm{~F}$ and $1492 \mathrm{R}$ as previously described by Ezeokoli et al. (2016a). Amplicons were then purified and sequenced as previously described (Bamidele et al. 2017). Following sequencing, sequences were inspected and

This article is protected by copyright. All rights reserved. 
manually edited using Chromas lite (v.2.1, Technelysium Pty Ltd) prior to aligning sequences against sequences in the EZBioCloud database (http://www.ezbiocloud.net/; Yoon et al. 2017). The 16S rRNA gene sequences obtained from this study are available in the GenBank under the accession numbers KY569461-KY569508. An operational taxonomic unit (OTU)-based taxonomic assignment of sequences was further performed by clustering sequences at $97 \%$ partial $16 \mathrm{~S}$ rRNA gene similarity, using the mothur software (Schloss et al. 2009) as described by Ezeokoli et al. (2016b).

For phylogenetic analyses of isolates, representative sequences of each phylotype (based on the closest hits obtained from alignment on the EzBioCloud database) along with closely related sequences in the database GenBank were aligned using Clustal X (version 2.0) multiple sequence alignment program (Larkin et al. 2007). The multiple sequence alignment was manually edited for gaps and ambiguous alignment positions in MEGA7 software (Kumar et al. 2016). Thereafter, a neighbour-joining phylogenetic tree was constructed in MEGA7 as previously described by Adedeji et al. (2017).

\section{Acknowledgements}

The molecular studies were supported by the South African National Research Foundation Thuthuka grant \#841688. The ARC-ISCW and the DNA Sequencing Unit of the Stellenbosch University, South Africa are acknowledged for providing facilities for molecular analyses.

\section{Conflict of Interest}

The authors have no conflict of interests to declare.

This article is protected by copyright. All rights reserved. 


\section{References}

Achi, O.K. (2005) Traditional fermented protein condiments in Nigeria. Afr J Biotechnol 4(13), 1612-1621.

Adedeji, B.S., Ezeokoli. O.T., Ezekiel, C.N., Obadina, A.O., Somorin, Y.M., Sulyok, M., Adeleke, R.A., Warth, B., Nwangburuka, C.C., Omemu, A.M., Oyewole, O.B. and Krska, R. (2017) Bacterial species and mycotoxin contamination associated with locust bean, melon and their fermented products in south-western Nigeria. Int $J$ Food Microbiol 258, 73-80.

Adelekan, A.O. and Nwadiuto, E. (2012) Bacterial succession studies during fermentation of African locust bean (Parkia biglobosa) to iru using molecular methods. Brit Biotechnol J 2(1), 49-59.

Aderibigbe, E.Y., Visessanguan, W., Sumpavapol, P. and Kongtong, K. (2011) Sourcing starter cultures for Parkia biglobosa fermentation I: Phylogenic grouping of Bacillus species from commercial iru samples. Int J Biotechnol Mol Biol Res 2(7), 121-127.

Adewumi, G.A., Oguntoyinbo, F.A., Keisam, S., Romi, W. and Jeyaram, K. (2013) Combination of culture-independent and culture-dependent molecular methods for the determination of bacterial community of iru, a fermented Parkia biglobosa seeds. Front. Microbiol. 3(436), 1-9.

Akinyele, B.J. and Oloruntoba, O.S. (2013) Comparative studies on Citrullus vulgaris, Citrullus colocynthis and Cucumeropsis mannii for ogiri production. Br Microbiol Res J 3(1), 1-18.

Aniche, G.N., Nwokedi, S.I. and Odeyemi, O. (1993) Effect of storage temperature, time and wrapping materials on the microbiology and biochemistry of ogiri - a fermented-castor seed soup condiment. World J Micriobiol Biotechnol 9, 653-655.

This article is protected by copyright. All rights reserved. 
Asagbra, A.E., Okafor, J.W.C., Onawola, O.O., Etoamaihe, M. and Olatope, S.O.A. (2012) Sensory properties of ogiri in Nigerian onugbu soup made from two varieties of melon seeds Cucumis melo and Cucumeropsis manii. Pak J Nutr 11(6), 596-599.

Barber, L., Achinewhu, S. and Ibiama, E. (1988) The microbiology of ogiri production from castor seed (Ricinus communis). Food Microbiol 5, 177-183.

Cazorla, F.M., Romero, D., Perez-Garcia, A., Lugtenberg, B.J., Vincente, A.D. and Bloemberg, G. (2007) Isolation and characterization of antagonistic Bacillus subtilis strains from the avocado rhizoplane displaying biocontrol activity. J Appl Microbiol 103, 1950-1959.

Chukeatirote, E., Chainun, C., Siengsubchart, A., Moukamnerd, C., Chantawannakul, P., Lumyong, S., Boontim, N. and Thakang, P. (2006) Microbiological and biochemical changes in Thua Nao fermentation. Res J Microbiol 1, 38-44.

David, O.M. and Aderibigbe, E.Y. (2010) Microbiology and proximate composition of ogiri, a pastry produced from different melon seeds. New York Sci J 3, 18-27.

Ezeokoli, O., Gupta, A., Popoola, T. and Bezuidenhout, C. (2016a) Molecular analysis of bacterial community dynamics during the fermentation of soy-daddawa condiment. Food Sci Biotechnol 25(4), 1081-1086.

Ezeokoli, O.T., Gupta, A.K., Mienie, C., Popoola, T.O.S. and Bezuidenhout, C.C. (2016b) PCR-denaturing gradient gel electrophoresis analysis of microbial community in soydaddawa, a Nigerian fermented soybean (Glycine max (L.) Merr.) condiment. Int J Food Microbiol 220, 58-62.

Ercolini, D. (2013) High-throughput sequencing and metagenomics: moving forward in the culture-independent analysis of food microbial ecology. Appl Environ Microbiol 79, 3148-3155.

This article is protected by copyright. All rights reserved. 
Janda, J.M. and Abbott, S.L. (2007) 16S rRNA gene sequencing for bacterial identification in the diagnostic laboratory: Pluses, perils, and pitfalls. J Clin Microbiol 45, 2761-2764.

Kothari, V.V., Kothari, R.K., Kothari, C.R., Bhatt, V.D., Nathani, N.M., Koringa, P.G., Joshi, C.G. and Vyas, B.R.M. (2013) Genome sequence of salt-tolerant Bacillus safensis strain VK, isolated from saline desert area of Gujarat, India. Genome Announc 1(5): e00671-13

Kumar, S., Stecher, G. and Tamura, K. (2016) MEGA7: Molecular Evolutionary Genetics Analysis version 7.0 for bigger datasets. Mol Biol Evol 33, 1870-1874.

Larkin, M.A., Blackshields, G., Brown, N.P., Chenna, R., McGettigan, P.A., McWilliam, H., Valentin, F., Wallace, I.M., Wilm, A., Lopez, R., Thompson, J.D., Gibson, T.J. and Higins, D.G. (2007) Clustal W and Clustal X version 2.0. Bioinformatics 23(21), 29472948.

Nwosu, C.D. and Ojimelukwe, P.C. (1993) Improvement of the traditional method of ogiri production and identification of the micro-organisms associated with the fermentation process. Plant Food Hum Nutr 43, 267-272.

Odibo, F., Nwabunnia, E., Ezekweghi, C. and Uzoeghe, E. (2012) Fermentation of Cucumeropsis seeds, an uncommon substrate for ogiri production. Afr $\mathrm{J}$ Microbiol Res 6, 5095-5099.

Odunfa, S.A. (1981) A note on the microorganisms associated with the fermentation of African locust bean (Parkia filicoidea) during iru production. Plant Food Hum Nutr 3, 245-250.

Odunfa, S.A. (1982) Biochemical changes during melon fermentation for ogiri production. $J$ Plant Food 4,111-116.

Odunfa, S.A. (1985) Microbiological and toxicological aspect of fermentation of castor oil seeds for ogiri production. J Food Technol 50, 1758-1759.

This article is protected by copyright. All rights reserved. 
Odunfa, S.A. and Oyewole, O.B. (1986) Identification of Bacillus species from 'iru', a fermented African locust bean product. J Basic Microbiol 26(2), 101-108.

Oguntoyinbo, F.A. (2012). Development of hazard analysis critical control points (HACCP) and enhancement of microbial safety quality during production of fermented legume based condiments in Nigeria. Nig Food J 30(1), 59-66.

Osho, A., Mabekoje, O.O. and Bello, O.O. (2009) Comparative study on the microbial load of gari, elubo-isu and iru in Nigeria. Afr J Food Sci 4(10), 646-649.

Ouoba, L.I.I., Rechinger, K.B., Barkholt, V., Diawara, B., Traore, A.S. and Jakobsen, M. (2003) Degradation of proteins during the fermentation of African locust bean (Parkia biglobosa) by strains of Bacillus subtilis and Bacillus pumilus for production of soumbala. J Appl Microbiol 94, 396-402.

Oyeyiola, G.P. (1988) Microbiology of the fermentation of 'iru pete' and 'iru woro' obtained from local producers. MIRCEN Journal 4, 439-445.

Schloss, P.D., Westcott, S.L., Ryabin, T., Hall, J.R., Hartmann, M., Hollister, E.B., Ryan, A., Lesniewski, R.A., Oakley, B.B., Parks, D.H., Robinson, C.J., Sahl, J.W., Stres, B., Thallinger, G.G., Van Horn, D.J. and Weber, C.F. (2009) Introducing mothur: opensource, platform-independent, community-supported software for describing and comparing microbial communities. Appl Environ Microbiol 75(23), 7537-7541.

Yoon, S.H., Ha, S.M., Kwon, S., Lim, J., Kim, Y., Seo, H. and Chun, J. (2017) Introducing EzBioCloud: A taxonomically united database of $16 \mathrm{~S}$ rRNA and whole genome assemblies. Int J Syst Evol Microbio/ 67, 1613-1617.

This article is protected by copyright. All rights reserved. 
Table 1. Taxonomic affiliations of isolates obtained during the processing of iru and ogiri based on EZBioCloud database matches of partial 16S rRNA gene.

\begin{tabular}{|c|c|c|c|c|c|c|}
\hline $\begin{array}{l}\text { Processing } \\
\text { stage }\end{array}$ & Lab ID & Closest hit on EzBioCloud & $\mathrm{N}^{\mathrm{a}}$ & $\mathrm{OTU}^{\mathrm{b}}$ & $\begin{array}{l}\text { Similarity } \\
(\%)\end{array}$ & $\begin{array}{l}\text { Accession } \\
\text { number }\end{array}$ \\
\hline \multicolumn{7}{|l|}{ Iru production } \\
\hline \multirow[t]{2}{*}{ Dried seeds } & RS01 & Bacillus anthracis & 16 & 2 & 100 & KY569461 \\
\hline & GS02 & Enterococcus dispar & 13 & 3 & 99.88 & KY569462 \\
\hline \multirow[t]{5}{*}{ Boiled seeds } & BDS09 & Bacillus anthracis & 3 & 2 & 100 & KY569468 \\
\hline & BDW05 & Bacillus encimensis & 4 & 6 & 100 & KY569464 \\
\hline & BDS08 & Bacillus subtilis subsp. inaquosorum & 9 & 1 & 100 & KY569467 \\
\hline & BDS07 & Enterococcus casseliflavus & 2 & 3 & 99.65 & KY569466 \\
\hline & BDW06 & Lysinibacillus macroides & 9 & 4 & 100 & KY569465 \\
\hline \multirow[t]{8}{*}{ Dehulling } & RW12-1 & Aerococcus urinaeequi & 10 & 8 & 100 & KY569471 \\
\hline & DS10 & Bacillus altitudinis & 2 & 1 & 100 & KY569469 \\
\hline & RW12-3 & Bacillus anthracis & 1 & 2 & 100 & KY569473 \\
\hline & RW13 & Bacillus encimensis & 3 & 6 & 100 & KY569474 \\
\hline & RW11 & Bacillus velezensis & 1 & 1 & 100 & KY569470 \\
\hline & RDW13-2 & Enterococcus gallinarum & 1 & 3 & 100 & KY569487 \\
\hline & RDW13-3 & Lysinibacillus macroides & 1 & 4 & 100 & KY569486 \\
\hline & RW14 & Proteus mirabilis & 2 & 5 & 100 & KY569475 \\
\hline \multirow{2}{*}{$\begin{array}{l}\text { River sand } \\
\text { sediment- } \\
\text { coated seeds }\end{array}$} & O23 & Bacillus safensis & 4 & 1 & 100 & KY569484 \\
\hline & $\mathrm{O} 24$ & Lysinibacillus fusiformis & 3 & 4 & 99.89 & KY569485 \\
\hline \multirow{3}{*}{$\begin{array}{l}\text { Reboiled } \\
\text { seed }\end{array}$} & RDS16 & Bacillus anthracis & 13 & 2 & 100 & KY569478 \\
\hline & RDS17 & Bacillus cytotoxicus & 4 & 2 & 100 & KY569479 \\
\hline & RDW15-1 & Micrococcus endophyticus & 3 & 12 & 100 & KY569476 \\
\hline \multirow{3}{*}{$\begin{array}{l}\text { Fermented } \\
\text { products (iru) }\end{array}$} & 12HR19 & Enterococcus faecium & 1 & 3 & 100 & KY569481 \\
\hline & 12HR18 & Lysinibacillus fusiformis & 4 & 4 & 99.87 & KY569480 \\
\hline & 24HR20 & Proteus mirabilis & 5 & 5 & 99.88 & KY569482 \\
\hline
\end{tabular}

Ogiri production

Shelled melon seeds

CFD

Bacillus safensis

NPS

Bacillus zhangzhouensis

FA Enterobacter cloacae subsp.

Cloacae

Washed

NTS

Bacillus safensis

MPF

Proteus mirabilis

$\begin{array}{llll}4 & 1 & 100 & \mathrm{KY} 569489 \\ 2 & 1 & 100 & \mathrm{KY} 569488 \\ 2 & 7 & 100 & \mathrm{KY} 569501 \\ 5 & 1 & 99.26 & \mathrm{KY} 569506 \\ 7 & 5 & 100 & \mathrm{KY} 569508\end{array}$

This article is protected by copyright. All rights reserved. 


\begin{tabular}{|c|c|c|c|c|c|c|}
\hline \multirow[t]{2}{*}{ Boiled seeds } & MPS & Acinetobacter variabilis & 3 & 10 & 100 & KY569505 \\
\hline & NBM & Bacillus safensis & 11 & 1 & 100 & KY569507 \\
\hline \multirow{7}{*}{$\begin{array}{l}\text { Fermented } \\
\text { product } \\
\text { (Batch A ogiri) }\end{array}$} & $\mathrm{COL}$ & Acinetobacter baumannii & 21 & 11 & 99.76 & KY569491 \\
\hline & SBN & Acinetobacter variabilis & 2 & 10 & 99.15 & KY569494 \\
\hline & FB_1 & Bacillus altitudinis & 1 & 1 & 100 & KY569499 \\
\hline & ME & Bacillus safensis & 30 & 1 & 100 & KY569492 \\
\hline & NMB & Bacillus siamensis & 3 & 1 & 100 & KY569497 \\
\hline & FA1 & Staphylococcus haemolyticus & 1 & 9 & 100 & KY569504 \\
\hline & FP & Staphylococcus schweitzeri & 4 & 9 & 99.76 & KY569503 \\
\hline \multirow{4}{*}{$\begin{array}{l}\text { Fermented } \\
\text { product } \\
\text { (Batch B ogiri) }\end{array}$} & MOK & Bacillus altitudinis & 6 & 1 & 100 & KY569493 \\
\hline & NCT & $\begin{array}{l}\text { Enterobacter cloacae subsp. } \\
\text { Cloacae }\end{array}$ & 1 & 7 & 99.88 & KY569495 \\
\hline & $\mathrm{FF}$ & Enterococcus faecium & 7 & 3 & 100 & KY569502 \\
\hline & MPA & Proteus mirabilis & 3 & 5 & 100 & KY569498 \\
\hline
\end{tabular}

${ }^{a}$ Number of isolates.

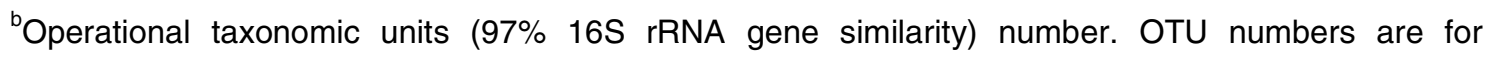
combined sequences of iru and ogiri (See also Fig. 4).

${ }^{\mathrm{c}}$ Accession number of representative phylotype.

This article is protected by copyright. All rights reserved. 


\section{Figure Captions}

Figure 1 16S rRNA gene sequence-based taxonomic distribution of isolates from iru processing. Percentages of isolates within bacterial phyla are shown as well as the relative percentage distribution of bacterial genera or species within each phylum.

Figure 2 16S rRNA gene sequence-based taxonomic distribution of isolates from ogiri processing. Percentages of isolates within bacterial phyla are shown as well as the relative percentage distribution of bacterial genera or species within each phylum.

Figure 3 Unrooted-Neighbour joining phylogenetic tree showing association of 16S rRNA gene sequences obtained from both iru and ogiri with sequences in the GenBank. Representative phylotypes from processing stages of each condiment were selected for phylogenetic reconstruction. Root tip labels with shaded triangles represent phylotypes from iru processing stages, while shaded circles represent phylotypes from ogiri processing stages. Accession numbers are in parenthesis. Bootstrap values (1000 replicates) $<50 \%$ are not shown.

Figure 4 Operational taxonomic units (OTUs) (97\% 16S rRNA gene similarity) associated with different stages of iru (a) and ogiri (b) condiment processing. OTU numbers for each processing point corresponds to the OTU numbers and taxonomic species listed against each condiment as described in Table 1.

\section{Supplementary Figure Caption}

Figure S1. Flowcharts for the production of iru (a) and ogiri (b).

This article is protected by copyright. All rights reserved. 


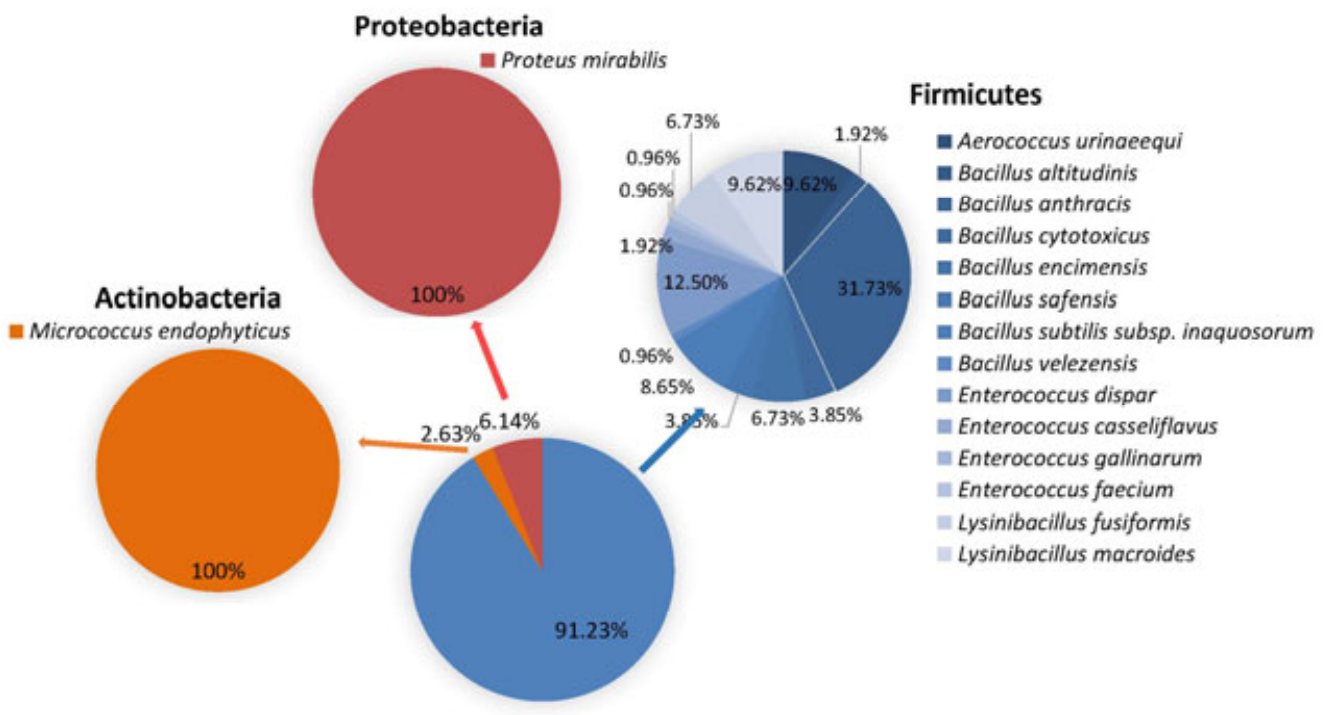

Figure 1

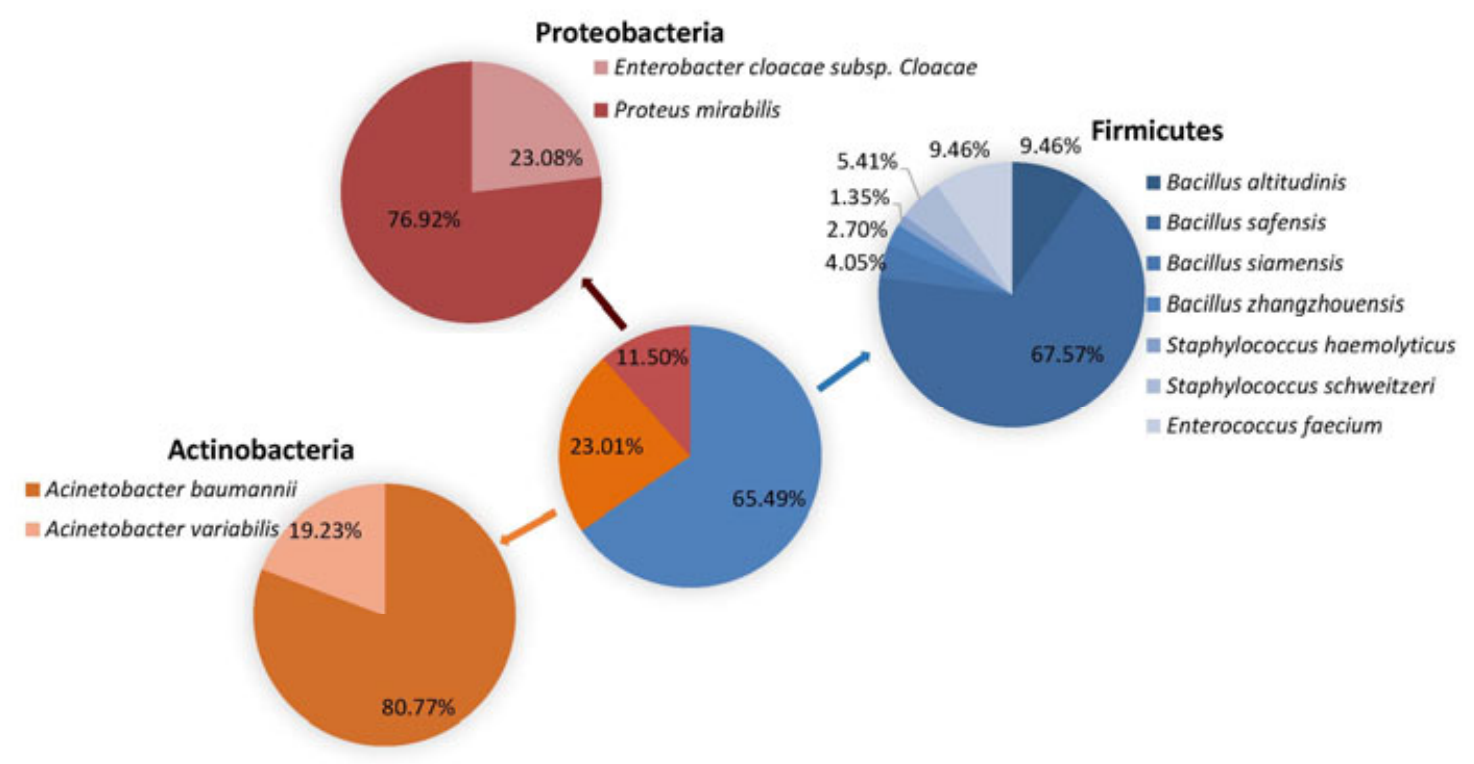

Figure 2

This article is protected by copyright. All rights reserved. 


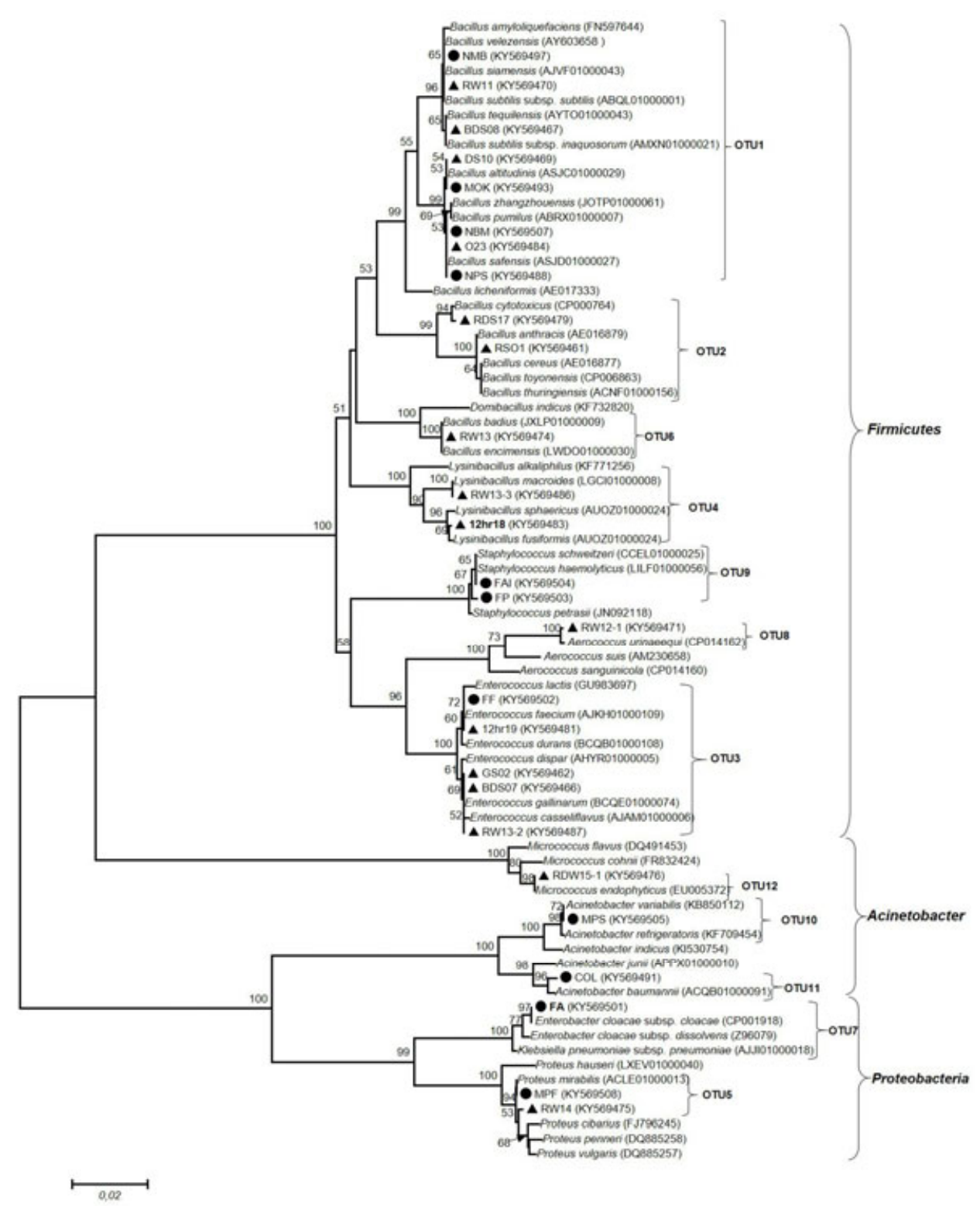

Figure 3

This article is protected by copyright. All rights reserved. 
a.

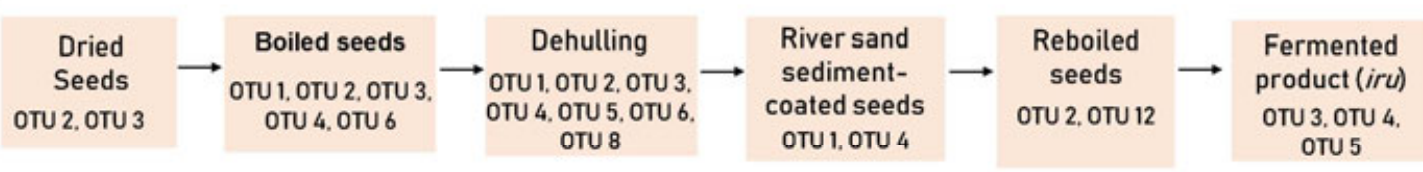

b.

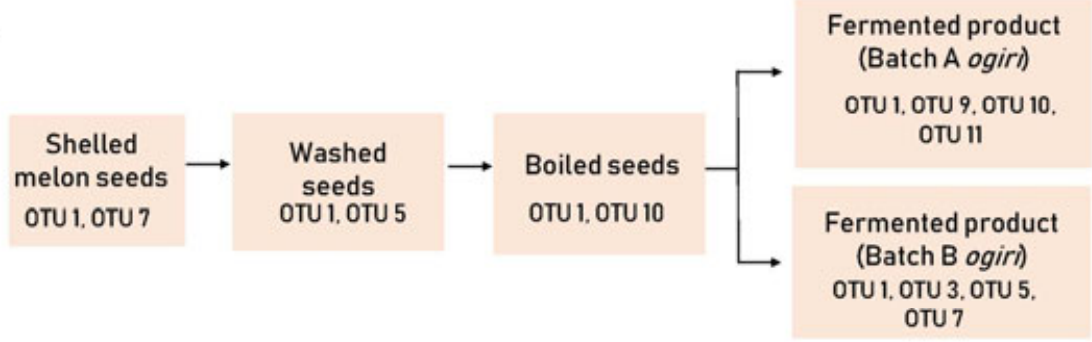

Figure 4

This article is protected by copyright. All rights reserved. 